\title{
MACROPHYTES AS EŁK RIVER QUALITY STATUS EVALUATION INDICATORS BASED ON EXAMPLE OF NICKEL
}

\author{
Elżbieta Skorbiłowicz' ${ }^{1}$ Mirosław Skorbiłowicz' ${ }^{1}$ Emilia Zamojska, \\ Piotr Ofman', Paulina Wójtowicz \\ 1 Department of Technology in Engineering and Environmental Protection, Bialystok University of Technology, \\ Wiejska 45A, 15-351 Bialystok, Poland, Corresponding Author e-mail: e.skorbilowicz@pb.edu.pl
}

Received: 2016.02.13

Accepted: 2016.06.01

Published: 2016.07.01

\begin{abstract}
The aim of the study was to analyze the content of $\mathrm{Ni}$ in fractions of $1.0-0.2 \mathrm{~mm}$, $0.2-0.1 \mathrm{~mm}, 0.1-0.063 \mathrm{~mm}, 0.063-0.02 \mathrm{~mm}$, and $<0.02 \mathrm{~mm}$ of river bottom sediments and plants (root, stem, leaf) of broadleaf cattail (Typha latifolia), yellow water lilies (Nuphar lutea), and cowbane (Cicuta virosa). Nickel content in bottom sediment was slightly higher than the geochemical background. The largest amounts of $\mathrm{Ni}$ were associated with the finest fraction, while the smallest with the thickest fraction. The highest content of this element was recorded at the point Ełk Barany, which was connected with developing industry in the city of Ełk. All of the tested plants showed greater $\mathrm{Ni}$ contents than the amount naturally occurring in plants. In most cases, most of $\mathrm{Ni}$ was associated with plant roots, and the least with leaves. It has been proven that aquatic plants can be good indicators of the aquatic environment status.
\end{abstract}

Keywords: river, nickel, bottom sediment, macrophytes

\section{INTRODUCTION}

Surface waters are an important part of the environment. They not only create the conditions for the existence of aquatic organisms, but also have an impact on climate, supplement the groundwater resources, meet the socio-economic functions not only in terms of consumption, but also aesthetic and recreational (Skorbiłowicz E. 2014). A threat to good quality of waters by intensive development of civilization is being observed (Hozhina et al., 2001). Heavy metals are the major threat to the aquatic environment and bottom sediments (Rabajczyk 2007, Aderinola O.J., Clarke E.O. 2009, Romanowska-Duda 2013). Rapidly developing agriculture, industry and transport exerts a significant impact on the pollution of rivers with heavy metals (Nocoń 2006, Yao 2014, Abdul Hameed M.J. Al Obaidy 2014). One of the metals derived from anthropogenic sources and having a toxic effect on aquatic organisms and also humans, is nickel (Barałkiewicz D., Siepak J. 1999, Kuziemska 2007). Macrophytes are excellent research material used in bio-indication of water systems (Rabajczyk 2008); these plants have the ability to selectively bioaccumulation elements, their temporary retention, and re-mobilization (Harasimiuk 2005). Macrophytes are biological filters having a big impact on the flow of chemicals within aquatic ecosystems. They are able to accumulate substances in concentrations exceeding their content in a specific environment (Carling et al. 2013). Demirezen and Aksony (2006) claim that aquatic plants reflect the metals contents in their environment.

The aim of the study was to determine contents of the nickel presence in bottom sediments and plants: Typha latifolia, Nuphar lutea, Cicuta virosa in river Ełk. Basing on nickel contents in water plants it is possible to choose its best indicator in aquatic environment. 


\section{DESCRIPTION OF THE OBJECT AND STUDY METHODS}

The study was carried out on the river Ełk (Figure 1), the catchment of which is located in the north-eastern part of Poland. Approximately $86 \mathrm{~km}$ of the river flows through the WarmińskoMazurskie province and the remainder is located in the Podlasie region $(27,4 \mathrm{~km})$. The catchment area of the river is about $1524.5 \mathrm{~km}^{2}$, its total length is $113.4 \mathrm{~km}$. The average annual value of the flow at the estuary is $10 \mathrm{~m}^{3} / \mathrm{s}$. The beginning of the river is located in Szeska Góra near Gołdap, and the estuary ends in the vicinity of Osowiec, where the river falls into the river Biebrza. The lower part of the river is Rudnicki Canal. Tributaries of river Ełk are: Mazurka, Połomska Młynówka, Gawlik, Karmelówka, Różanica, Kuwasy Canal. In the city of Ełk, the river falls into the Lake Ełckie in its central part and flows out from its south-western bay. The river catchment is dominated by lessive (36\%) and brown acidic soils (27\%); the others are specific brown, chernozem, and rusty soils. There are two sewage treatment plants in the catchment of the studied river; wastewater is also discharged from smaller housing estates into the river. Industry develops quite intensively within the catchment area of the river. Production facilities are located in larger towns, through which the river flows (Ełk, Nowa Wieś Ełcka, Prostki, Grajewo). The dairy, meat, paper, construction, and wood industries dominate. The catchment areas are moderately populated, and an intense development of tourism can be observed.

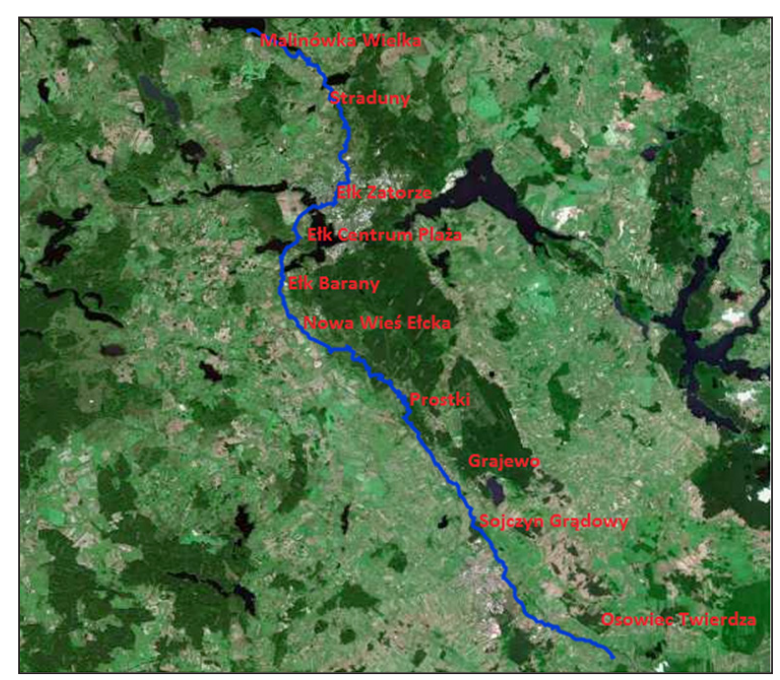

Figure 1. Localization of measurement points
Ten measurement points were selected on the river Ełk (according to main pollution sources as: sewage treatment plant, transport and surface flows from fields), from which samples of bottom sediments and macrophytes were collected. Samples of plants and bottom sediments from the river were collected during the extensive vegetation in 2014. The dominant species were: broadleaf cattail (Typha latifolia), yellow water lily (Nuphar lutea), and cowbane (Cicuta virosa). Typha latifolia, Nuphar lutea, Cicuta virosa were transferred to laboratory, dried and prepared to analyzes. Samples of bottom sediment were subject to a sieve analysis. Each fraction $(1.0-0.2 \mathrm{~m}$; $0.2-0.1 \mathrm{~mm} ; 0.1-0.063 \mathrm{~mm} ; 0.063-0.02 \mathrm{~mm}$; $<0.02 \mathrm{~mm}$ ) was combusted in an oven at about $550{ }^{\circ} \mathrm{C}$, then mineralized in teflon containers in aqua regia. The nickel content was determined by means of ASA with inductively coupled flame on spectrometer Varian Spectr AA 100. Macrophytes were divided into parts (leaf, stem, root) and subject to combustion in an oven at $550{ }^{\circ} \mathrm{C}$. The achieved ash was digested in nitric acid and $30 \%$ hydrogen peroxide in a digestion block.

The obtained results of nickel contents are given in respect to air-dry bottom sediments and compared with literature data. To assess the extent of sediment contamination with nickel, the proposed classification of aquatic sediments in Poland based on geochemical criteria was used (Bojakowska, Sokołowska 1998, Bojakowska 2001). The physiological norm of nickel content for aquatic plants was indicated according to data presented by Kabata-Pendias, Pendias [1999]. Nickel bioaccumulation coefficient was calculated as the ratio of nickel concentration in roots to its content in bottom sediments. On the basis of nickel content in various parts of plants, the index of translocation of the element between roots and stems and roots and leaves, was specified.

Parametric Pearson correlation coefficients were calculated to demonstrate the correlation between plants and their environment. Statistical analyzes included an evaluation of Pearson correlation coefficients (R) in a system: bottom sediment - macrophytes. Sediment fractions and individual parts of plants, i.e. root, stem, and leaf, were taken into account. All statistical calculations were performed using Statistica 10 in Polish language version working on Windows 7 Home Edition platform. 


\section{RESULTS AND DISCUSSION}

Mean nickel concentrations ranged from 5.09 to $6.56 \mathrm{mg} \cdot \mathrm{kg}^{-1} \mathrm{DM}$ (Table 1). Its major part was associated with the finest fractions (0.063-0.02 $\mathrm{mm} ;<0.02 \mathrm{~mm}$ ), while the least amounts with the thickest one $(1.0-0.2 \mathrm{~mm})$. Similar dependence was reported by Skorbiłowicz (2011) in studies on river Górna Narew and its tributaries. The range of Ni content in the individual fractions varied from 1.60 (fractions $1.0-0.2 \mathrm{~mm}$ ) up to $15.60 \mathrm{mg} \cdot \mathrm{kg}^{-1} \mathrm{DM}$ (fractions $<0.02 \mathrm{~mm}$ ). For instance, nickel content in bottom sediment of river Kłodnica oscillated from $1 \mathrm{mg} \cdot \mathrm{kg}^{-1} \mathrm{DM}$ up to 30 $\mathrm{mg} \cdot \mathrm{kg}^{-1}$ DM (Nocoń, Barbusiński 2011). Much higher contents of the element were recorded by Gołdyn et al. (2015) in studies performed in water courses of Western Poland. Average Ni contents, reported by those authors amounted to 22.27 $\mathrm{mg} \cdot \mathrm{kg}^{-1} \mathrm{DM}$. When comparing the Ni content in the individual fractions of river bottom sediment, it was found that average content of this element slightly exceeded the limit for geochemical background. It should be noted that none of the maximum contents of this element was greater than the limit for class I of sediments in accordance with values provided by Bojakowska and Sokołowska (1998).

The nickel content in bottom sediments was related to the placement of measuring points. The highest concentrations of nickel in all fractions was recorded at measurement point Ełk Barany (10.5 to $15.6 \mathrm{mg} \cdot \mathrm{kg}^{-1} \mathrm{DM}$ ), which can be associated with intense industry development in the city of Ełk (Figure 2). There are two more important points considering the most developed city areas which are Osowiec Twierdza point and Grajewo point. The element levels varied from 4,7 to $9.9 \mathrm{mg} \cdot \mathrm{kg}^{-1} \mathrm{DM}$ in mentioned above points.
At other measurement points, nickel contents in $1.0-0.2 \mathrm{~mm}, 0.2-0.1 \mathrm{~mm}$, and $0.1-0.063 \mathrm{~mm}$ fractions were uniform and ranged from about 3 to about $6 \mathrm{mg} \cdot \mathrm{kg}^{-1} \mathrm{DM}$.

Nickel contents in particular parts (root, stem, leaf) were subject to considerable variation. The highest content of this element was observed in the case of broadleaf cattail and cowbane in roots, whereas the yellow water lily in the stem. Large metals contents in roots and low concentrations in leaves or stems indicate that sediments are not a major source of metals and only a small proportion is transferred to the above ground parts (Baldontoni et al. 2004). Among tested species, the highest average nickel content (Table 2) was found at broadleaf cattail $\left(4.71 \mathrm{mg} \cdot \mathrm{kg}^{-1}\right)$, then cowbane $\left(4.62 \mathrm{mg} \cdot \mathrm{kg}^{-1}\right)$, and yellow water lily $\left(4.12 \mathrm{mg} \cdot \mathrm{kg}^{-1}\right)$. When comparing these results to literature data reported by Kabata-Pendias and Pendias (1999), it was found that the test plants were slightly contaminated by this element.

Among the considered plant species, the largest amounts of $\mathrm{Ni}$ were accumulated by broadleaf cattail. In particular measurement points, the content of this element in the whole plant varied in the range from 4.3 to $23.6 \mathrm{mg} \cdot \mathrm{kg}^{-1} \mathrm{DM}$. The highest nickel concentration at this plant was observed at the point Ełk Zatorze, while the lowest in Straduny (Figure 3). Yellow water lily was characterized by the highest Ni level at point Malinówka Wielka (21.95 mg $\left.\mathrm{kg}^{-1} \mathrm{DM}\right)$, whereas the lowest in Grajewo $\left(6.2 \mathrm{mg} \cdot \mathrm{kg}^{-1} \mathrm{DM}\right)$. In the case of cowbane, the variability range for the element was from 6.25 to $19.9 \mathrm{mg} \cdot \mathrm{kg}^{-1} \mathrm{DM}$. Minimum content was recorded in Sojczyno Grądowe, while maximum in Ełk C. Plaża. Maximum Ni contents in the case of yellow water lily and cowbane did not overlap with the point, where maximum $\mathrm{Ni}$ content in bottom sediment was recorded (Figure 3).

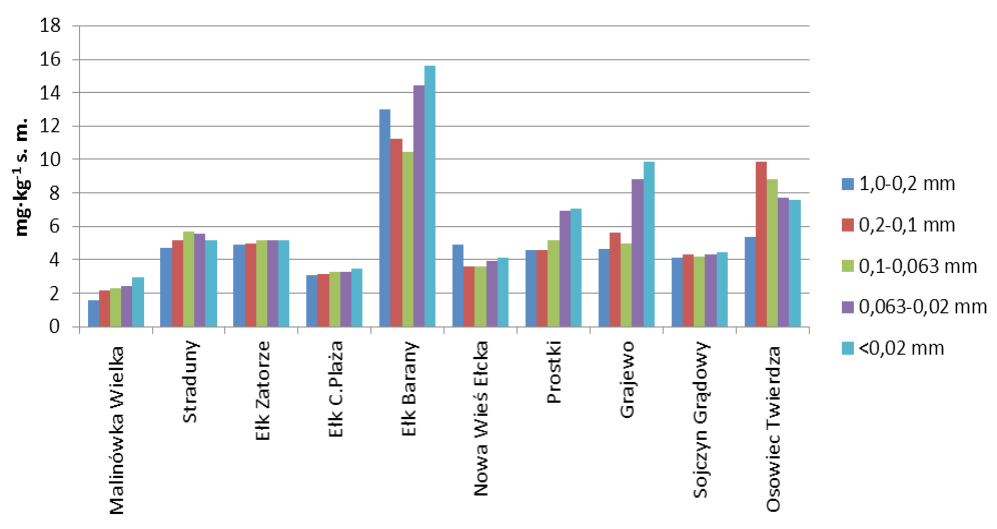

Figure 2. Contents of $\mathrm{Ni}$ in the individual fractions of the river bottom sediment 
Table 1. Basic statistical parameters for Ni content in the individual fractions of river Ełk bottom sediment

\begin{tabular}{|c|c|c|c|c|c|}
\hline Fractions & Unit & Mean & Minimum & Maximum & Standard deviation \\
\hline $1.0-0.2 \mathrm{~mm}$ & \multirow{5}{*}{$\mathrm{mg} \cdot \mathrm{kg}^{-1} \mathrm{DM}$} & 5.09 & 1.60 & 13.00 & 2.99 \\
\hline $0.2-0.1 \mathrm{~mm}$ & & 5.47 & 2.15 & 11.25 & 2.90 \\
\hline $0.1-0.063 \mathrm{~mm}$ & & 5.37 & 2.30 & 10.45 & 2.51 \\
\hline $0.063-0.02 \mathrm{~mm}$ & & 6.26 & 2.45 & 14.45 & 3.51 \\
\hline$<0.02 \mathrm{~mm}$ & & 6.56 & 2.95 & 15.60 & 3.81 \\
\hline
\end{tabular}

Table 2. Basic statistical parameters for Ni content in the individual plant organs

\begin{tabular}{|c|c|c|c|c|c|c|}
\hline Plant & Organ & Unit & Mean & Minimum & Maximum & $\begin{array}{l}\text { Standard } \\
\text { deviation }\end{array}$ \\
\hline \multirow{3}{*}{ Yellow Water Lily } & root & \multirow{9}{*}{$\mathrm{mg} \cdot \mathrm{kg}^{-1} \mathrm{DM}$} & 5.08 & 2.35 & 8.55 & 2.20 \\
\hline & stem & & 5.09 & 1.30 & 9.55 & 3.06 \\
\hline & leaf & & 3.17 & 0.90 & 4.95 & 1.55 \\
\hline \multirow{3}{*}{ Broadleaf Cattail } & root & & 5.08 & 2.10 & 9.80 & 3.05 \\
\hline & stem & & 4.58 & 1.15 & 8.55 & 2.32 \\
\hline & leaf & & 4.49 & 0.50 & 9.80 & 2.61 \\
\hline \multirow{3}{*}{ Cowbane } & root & & 6.09 & 2.60 & 10.20 & 2.50 \\
\hline & stem & & 3.75 & 0.80 & 7.85 & 2.32 \\
\hline & leaf & & 4.03 & 1.15 & 9.60 & 2.33 \\
\hline
\end{tabular}

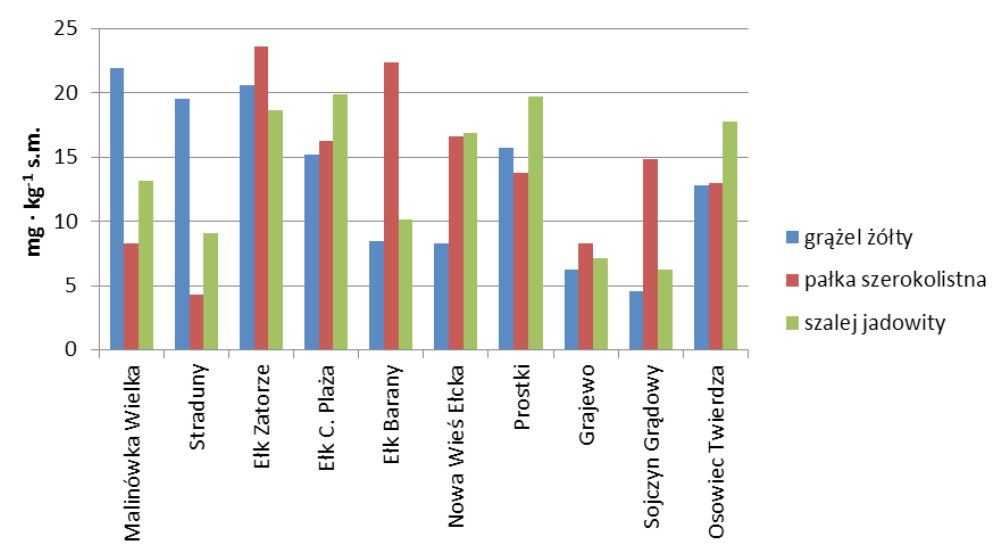

Figure 3. Nickel contents in the individual macrophytes

In order to evaluate the transfer of $\mathrm{Ni}$ from the bottom sediments to the roots, the bioaccumulation coefficient was calculated (Table 3 ). The index value below a unit testifies the low nickel movement from sediments into the plant. The study showed that WB in most cases was equal to or greater than unit indicating the nickel intake from the environment. In the case of all test plants, the largest bioaccumulation coefficients were observed for fraction $1.0-0.2 \mathrm{~mm}$, while the smallest for $<0.02$ $\mathrm{mm}$ fraction. Broader range of bioaccumulation coefficients than those in river Ełk was recorded by Bonanno (2013) in studies upon aquatic vegetation in Catania. The author, when studying Typha domingensis, Phragmites australis, and Arundo donax, determined the bioaccumulation coefficients equal respectively to $2.44,0.43$, and 0.16 .

The translocation index (TF) provides with information on the internal transport of metals within a plant. The TF in the case of broadleaf cattail amounted to more than a unit suggesting a high ability of nickel penetration from roots to the above ground parts of plants. The adverse situation was observed for cowbane and yellow water lily. Ana I. Sousa et al. (2007) calculated the translocation index between metals contents in roots and stems of Portulacoides halimione - plant species inhabiting the aquatic areas with elevated salinity. Value of the translocation index for nickel was $0.55-0.24$. 
Table 3. Basic statistical parameters for bioaccumulation coefficient (WB) and translocation index (TF) at test plants

\begin{tabular}{|c|c|c|c|c|c|}
\hline Plant & Fraction/Indicator & Mean & Minimum & Maximum & $\begin{array}{l}\text { Standard } \\
\text { deviation }\end{array}$ \\
\hline \multirow{7}{*}{ Yellow Water Lily } & $1.0-0.2 \mathrm{~mm} \mathrm{WB}$ & 1.44 & 0.28 & 5.34 & 1.47 \\
\hline & $0.2-0.1 \mathrm{~mm}$ WB & 1.26 & 0.32 & 3.98 & 1.09 \\
\hline & $0.1-0.063 \mathrm{~mm}$ WB & 1.21 & 0.35 & 3.72 & 1.00 \\
\hline & 0.063- $0.02 \mathrm{~mm}$ WB & 1.12 & 0.25 & 3.49 & 0.96 \\
\hline & $<0.02 \mathrm{~mm} \mathrm{WB}$ & 1.05 & 0.23 & 2.90 & 0.81 \\
\hline & Ł-K TF & 0.95 & 0.55 & 1.57 & 0.29 \\
\hline & L-K TF & 0.63 & 0.35 & 1.02 & 0.22 \\
\hline \multirow{7}{*}{ Broadleaf Cattail } & $1.0-0.2 \mathrm{~mm} \mathrm{WB}$ & 1.19 & 0.43 & 2.84 & 0.85 \\
\hline & $0.2-0.1 \mathrm{~mm}$ WB & 1.10 & 0.36 & 2.79 & 0.79 \\
\hline & $0.1-0.063 \mathrm{~mm}$ WB & 1.08 & 0.40 & 2.71 & 0.75 \\
\hline & 0.063- $0.02 \mathrm{~mm}$ WB & 0.99 & 0.29 & 2.67 & 0.77 \\
\hline & $<0.02 \mathrm{~mm} \mathrm{WB}$ & 0.94 & 0.26 & 2.51 & 0.72 \\
\hline & Ł-K TF & 1.07 & 0.43 & 2.26 & 0.66 \\
\hline & L-K TF & 1.19 & 0.19 & 4.67 & 1.28 \\
\hline \multirow{7}{*}{ Cowbane } & $1.0-0.2 \mathrm{~mm} \mathrm{WB}$ & 1.66 & 0.24 & 4.78 & 1.37 \\
\hline & $0.2-0.1 \mathrm{~mm} \mathrm{WB}$ & 1.50 & 0.28 & 3.56 & 1.12 \\
\hline & $0.1-0.063 \mathrm{~mm}$ WB & 1.45 & 0.30 & 3.33 & 1.04 \\
\hline & 0.063- $0.02 \mathrm{~mm}$ WB & 1.34 & 0.22 & 3.12 & 1.02 \\
\hline & $<0.02 \mathrm{~mm}$ WB & 1.26 & 0.20 & 2.91 & 0.89 \\
\hline & Ł-K TF & 0.62 & 0.17 & 1.16 & 0.32 \\
\hline & L-K TF & 0.71 & 0.28 & 1.24 & 0.35 \\
\hline
\end{tabular}

explanations: $\mathrm{K}$ - root, $\mathrm{L}$ - stem, L - leaf

Table 4. Correlations between bioaccumulation coefficients and translocation indices

\begin{tabular}{|c|c|c|c|c|c|c|c|}
\hline & $\begin{array}{c}1.0-0.2 \mathrm{~mm} \\
\text { WB }\end{array}$ & $\begin{array}{c}0.2-0.1 \mathrm{~mm} \\
\text { WB }\end{array}$ & $\begin{array}{c}0.1-0.063 \\
\mathrm{~mm} \mathrm{WB}\end{array}$ & $\begin{array}{c}0.063-0.02 \\
\mathrm{~mm} \text { WB }\end{array}$ & $\begin{array}{c}<0.02 \mathrm{~mm} \\
\text { WB }\end{array}$ & Ł-K TF & L-K TF \\
\hline $1.0-0.2 \mathrm{~mm}$ WB & 1.00 & $\mathbf{0 . 9 5}$ & $\mathbf{0 . 9 5}$ & $\mathbf{0 . 9 5}$ & $\mathbf{0 . 9 3}$ & -0.21 & $-\mathbf{0 . 3 6}$ \\
\hline $0.2-0.1 \mathrm{~mm}$ WB & $\mathbf{0 . 9 5}$ & 1.00 & $\mathbf{1 . 0 0}$ & $\mathbf{0 . 9 7}$ & $\mathbf{0 . 9 5}$ & -0.19 & -0.34 \\
\hline $0.1-0.063 \mathrm{~mm}$ WB & $\mathbf{0 . 9 5}$ & $\mathbf{1 . 0 0}$ & 1.00 & $\mathbf{0 . 9 7}$ & $\mathbf{0 . 9 5}$ & -0.18 & -0.33 \\
\hline $0.063-0.02 \mathrm{~mm}$ WB & $\mathbf{0 . 9 5}$ & $\mathbf{0 . 9 7}$ & $\mathbf{0 . 9 7}$ & 1.00 & $\mathbf{1 . 0 0}$ & -0.18 & -0.29 \\
\hline$<0.02 \mathrm{~mm}$ WB & $\mathbf{0 . 9 3}$ & $\mathbf{0 . 9 5}$ & $\mathbf{0 . 9 5}$ & $\mathbf{1 . 0 0}$ & 1.00 & -0.19 & -0.29 \\
\hline Ł-K TF & -0.21 & -0.19 & -0.18 & -0.18 & -0.19 & 1.00 & $\mathbf{0} .37$ \\
\hline L-K TF & $\mathbf{- 0 . 3 6}$ & -0.34 & -0.33 & -0.29 & -0.29 & $\mathbf{0 . 3 7}$ & 1.00 \\
\hline
\end{tabular}

In the set of variables, statistically significant correlations at the level of $\alpha=0.05$ were observed between the contents of $\mathrm{Ni}$ in the individual fractions of river bottom sediment and between different parts of aquatic plants. The determined coefficients were characterized by strong positive associations and for each sediment fraction they ranged from $\mathrm{R}=0.85$ to $\mathrm{R}$ $=0.99$. In the case of macrophytes, associations between various parts of plants were not as strong as for the sediment. The range of variation of correlation coefficient was from $\mathrm{R}=0.45$ to $\mathrm{R}=0.59$ (Ni root - stem $\mathrm{r}=0.59$; Ni root - leaf $\mathrm{r}=0.45$; Ni stem - leaf $\mathrm{r}=05$ ). The ratio of $\mathrm{Ni}$ content in sediment fractions and particular parts of plants was very poor.

Table 4 shows the correlation coefficients between nickel bioaccumulation indicators for individual fractions of the river bottom sediments and translocation indices. Statistically significant connections between different indicators of bioaccumulation were characterized by very strong correlation. In the case of translocation indices, moderate correlation $(0.37)$ between value obtained for the pairs of stem-root and leaf-root, was recorded. This shows that the 
highest contents of $\mathrm{Ni}$ were accumulated in the root, and only a small portion of the metal was accumulated in leaves and stems.

\section{CONCLUSIONS}

1. The river bottom sediments collected from river Ełk contained $\mathrm{Ni}$ in amounts slightly exceeding the geochemical background for this element. Most of nickel was connected with the finest sediment fractions, i.e. $0.063-0.02$ $\mathrm{mm}$ and $<0.02 \mathrm{~mm}$.

2. Nickel content in fractions was observed in river bottom sediment collected from the point of Ełk Barany; this point is associated with industrial pollution coming from the production facilities in the city of Elk.

3. All tested plant species showed an increased $\mathrm{Ni}$ contents at particular measurement points. However, these values were not much higher than the natural content of the element. This fact indicates the presence of a source of aquatic plants enrichment in this element within the test area.

4. In most cases, the largest nickel concentrations were accumulated by test macrophytes in roots, while the least in leaves.

5. It was proven that aquatic plants (especially water stick) can be good indicators of the aquatic environment status.

\section{REFERENCES}

1. Abdul Hameed M. J. Al Obaidy, Athmar A.M. Al Mashhady, Eman S. Awad, Abass J. Kadhem. 2014. Heavy Metals Pollution in Surface Water of Mahrut River, Diyala, Iraq. International Journal of Advanced Research, 2(10), 1039-1044.

2. Abstr.Hong Yao, Xin Qian, Hailong Gao, Yulei Wang, Bisheng Xia, 2014. Seasonal and Spatial Variations of Heavy Metals in Two Typical Chinese Rivers: Concentrations, Environmental Risks, and Possible Sources. Int J Environ Res Public Health, 11(11), 11860-11878.

3. Ana I. Sousa, Isabel Cacador, Ana I. Lillebø, Miguel A. Pardal 2008. Heavy metal accumulation in Halimione portulacoides: Intra- and extra-cellular metal binding sites. Science Direct Chemosphere, 70, 850-857.

4. Barałkiewicz D., Siepak J., 1999. Chromium, nickel and cobalt in environmental samples and existing legal norms. Environmental Studies, 4, 201-208.
5. Barbusinski, K., Nocon, W. 2011. Heavy Metal Compoundsin the Bottom Sediments of the River Klodnica (Upper Silesia). Ochrona Srodowiska, 33(1), 13-17.

6. Bojakowska I. Sokołowska G., 1998. Geochemiczne klasy czystości osadów wodnych, Przeg.Geolog. 46, 1, 49-54.

7. D. Demirezen, A. Aksoy, 2006. Common hydrophytes as bioindicators of iron and manganese pollutions, Ecol. Indic. 6, 388-393.

8. G.T. Carling, D.C. Richards, H. Hoven, T. Miller, D.P. Fernandez, A. Rudd, E. Pazmino, W.P. Johnson, 2013. Relationships of surface water, porewater, and sediment chemistry in wetlands adjacent to Great Salt Lake, Utah, and potential impacts on plant community health, Sci. Total Environ. 443, 798-811.

9. Harasimiuk A. 2005. Bioakumulacja elementów w roślinach uprawnych i glebach. Wydział Geografii i Studiów Regionalnych, Uniwersytet Warszawski, 239-256.

10. Hozhina E.I., Khramov A.A., Gerasimov P.A., Kumarov A.A., 2001. Uptake of heavy metals, arsenic and antymony by aquatic plants in the vicinity of ore mining and processing industries. J. Geochem. Explor. 74, 153-162.

11. Kabata- Pendias A., Pendias H. 1999. Biochemia pierwiastków śladowych, PWN, Warszawa

12. Kuziemska B., Kalembasa S. 2010. Wpływ zanieczyszczenia gleby niklem oraz stosowania wapniowania i substancji organicznych na zawartość żelaza, manganu i cynku w kupkówce pospolitej. Ochrona Środowiska i Zasobów Naturalnych, 42, 100-108.

13. Nocoń W. 2006. Zawartość metali ciężkich w osadach dennych rzeki Kłodnicy, Ochrona Środowiska, 3, 39-44

14. O.J. Aderinola, E.O. Clarke, O.M. Olarinmoye, Kusemiju and M.A. Anatekhai 2009. Heavy Metals in Surface Water, Sediments, Fish and Perwinkles of Lagos Lagoon, American-Eurasian J. Agric. \& Environ. Sci., 5 (5), 609-617.

15. Rabajczyk A., Jóźwiak M.A. 2008. Możliwości wykorzystania makrofitów jako bioindykatorów metali ciężkich zdeponowanych w osadach dennych. Towarzystwo Naukowe, Kielce. Monitoring Środowiska Przyrodniczego, 9, 19-26.

16. Romanowska-Duda Z. 2013. Metale ciężkie jako specyficzne zanieczyszczenia środowiska wodnego, Uniwersytet Łódzki, Wydział Biologii i Ochrony Środowiska www.bioenergiadlaregionu.eu

17. Skorbiłowicz E. 2014. Zink and lead in bottom sediments and aquatic plants in river Narew, Journal of Ecological Engineering, 16(1), 132-139

18. Skorbiłowicz E., Skorbiłowicz M. 2011. Metals in grain fraction of bottom sediments form selected rivers in North- ekstern Poland. Physics and Chemistry of the Earth, 36, 567-578. 